УДК: 617.583-001.4-089.843-031:616.748.53-032

DOI.ORG/10.37647/0132-2486-2020-107-4-28-34

\title{
Medial Gastrocnemius Flap for Covering Tissue Defects Around the Knee
}

\author{
Liabakh A.P., Lazarenko H.M., Kulieva O.V. \\ SI "Institute of Traumatology and Orthopedics of NAMS of Ukraine", Kyiv
}

\begin{abstract}
Summary. Tissue defects of the anterior surface of the lower leg and the knee joint is a severe problem at the treatment of orthopedic patients. Objective. Analysis of the results of using the medial gastrocnemius flap (MGF) in orthopedic patients; bighlighting peculiarities of surgical technique. Materials and Methods. 8 patients (10 cases) who underwent the transposition of the MGF. The age of the patients was 19-74 years (on average $40.5 \pm 5.7$ years); there were 6 males and 2 females. The list of cases: open fractures -2 cases, combat injury - 2 patients (3 cases), skin necrosis after osteosynthesis - 3 patients (4 cases), and skin necrosis after total knee replacement - 1 case. The results of treatment were assessed in terms 9 months - 10 years by the Lysholm scale. Results. Autodermoplasty during MGF transposition was performed in two cases and after a few days in others. In cases with open fractures, the osteosynthesis and external fixators reassembly were done; conversion of osteosynthesis was performed one month after autodermoplasty. In cases of skin necrosis after osteosynthesis and total arthroplasty, the implants were never removed. Knee function according to the Lysholm scale ranged from 70 to 100 points

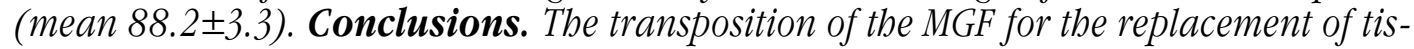
sue defects of the anterior surface of the lower leg and knee joint is an effective method in orthopedic surgery, which helps to solve the problem of infectious complications and to save the supporting-kinematic function of the lower extremity.
\end{abstract}

Key words: lower leg; medial gastrocnemius flap; open fracture; tissue defect.

\section{Introduction}

The anterior surface of the upper third of the tibia and knee joint is covered with inelastic skin and a thin subcutaneous tissue, which are close to the underlying bone. Tissue defects in this area occur due to various reasons: trauma, complications during arthroplasty, treatment of tumors, etc.

Timely and adequate closure of the tissue defect in this area is decisive for maintaining the function of the knee joint, and in some cases - for preserving the lower limb. Since Mathes S.J. and Nahai F. [1] established the anatomical possibilities of using the medial head of m.gastrocnemius as an island flap for covering tissue defects of the anterior surface of the upper third of the lower leg, this surgical technique is successfully used in traumatological and oncological cases [2-4]. Significant advantages of the medial head of m.gastrocnemius (medial gastrocnemius flap - MGF) are permanent vascular anatomy, simple elevating technique, mobility, and minimal loss of the donor site [5].

This study was carried out to analyze the outcome of using a medial gastrocnemius flap in orthopedic and traumatological patients, and to highligh peculiarities of surgical technique.

\section{Material and Methods}

This study was carried out at the Department of Foot Pathology and Complex Prosthesis (SI "Institute of Traumatology and Orthopedics of NAMS of Ukraine") in accordance with the Declaration of Helsinki (1975), as revised in 2008. Informed consent was taken from all the patients.

Eight patients (10 cases) who underwent MGF transposition were under our observation. The age of the patients was $19-74$ years (on average $40.5 \pm 5.7$ years); there were 6 males and 2 females. The indication for MGF transposition was a tissue defect on the anterior surface of the knee and upper third of the lower leg, which topographically corresponded to the area from the lower pole of the patella to the border of the proximal and middle third of the lower leg. The detailed characteristics of patients are presented in Table 1.

Surgical technique. Prevention of thromboembolic complications and antibiotic therapy was carried out according to the current hospital guidelines. The patients were operated on under general or spinal anesthesia in the supine position; it was obligatory to use a tourniquet at the level of the inguinal fold.

The initial stage included: recipient wound debridement, revision of pockets and heats, and repeated wash- 
Clinical characteristics of patients enrolled in the study

\begin{tabular}{|c|c|c|c|c|c|c|}
\hline No & Diagnosis & Sex & Age & $\begin{array}{l}\text { Time since injury/ } \\
\text { complication }\end{array}$ & $\begin{array}{l}\text { Orthopedic component } \\
\text { of reconstruction }\end{array}$ & $\begin{array}{l}\text { Knee function after } \\
\text { surgery according to } \\
\text { the Lysholm scale }\end{array}$ \\
\hline 1. & $\begin{array}{l}\mathrm{AO} 41 \mathrm{~A} 3 \\
\text { G-A II }\end{array}$ & $\mathrm{f}$ & 19 & $48 \mathrm{hrs}$ & Internal\&External fixation & 100 \\
\hline 2. & $\begin{array}{l}\mathrm{AO} 41 \mathrm{~A} 2 \\
\text { G-A IIIA }\end{array}$ & $\mathrm{m}$ & 44 & $72 \mathrm{hrs}$ & External fixation & 100 \\
\hline 3. & $\begin{array}{c}\mathrm{AO} 41 \mathrm{C} 2 \\
\text { Skin necrosis after surgery }\end{array}$ & $\mathrm{m}$ & 35 & $24 \mathrm{hrs}$ & None & 83 \\
\hline 4. & $\begin{array}{c}\mathrm{AO} 41 \mathrm{C} 2 \\
\text { Skin necrosis after surgery }\end{array}$ & $\mathrm{m}$ & 35 & 24 hrs & None & 83 \\
\hline 5. & $\begin{array}{c}\mathrm{AO} 41 \mathrm{C} 2 \\
\text { Skin necrosis after surgery }\end{array}$ & $\mathrm{m}$ & 50 & $24 \mathrm{hrs}$ & None & 98 \\
\hline 6. & $\begin{array}{c}\text { Mine-blast injury } \\
\text { AO 41 A2 } \\
\text { G-A IIIB } \\
\end{array}$ & $\mathrm{m}$ & 23 & 1 week & $\begin{array}{l}\text { Reassembly of external } \\
\text { fixation, osteosynthesis } \\
\text { conversion } \\
\end{array}$ & 82 \\
\hline 7. & $\begin{array}{l}\text { Mine-blast injury } \\
\text { AO } 41 \text { C2 } \\
\text { G-A IIIB } \\
\end{array}$ & $\mathrm{m}$ & 23 & 1 week & $\begin{array}{c}\text { Reassembly of external } \\
\text { fixation, osteosynthesis } \\
\text { conversion }\end{array}$ & 83 \\
\hline 8. & $\begin{array}{c}\text { Gunshot injury } \\
\text { AO } 41 \text { C2 } \\
\text { G-A IIIB } \\
\end{array}$ & $\mathrm{m}$ & 37 & 2 weeks & $\begin{array}{l}\text { Reassembly of external } \\
\text { fixation, osteosynthesis } \\
\text { conversion } \\
\end{array}$ & 100 \\
\hline 9. & $\begin{array}{c}\mathrm{AO} 41 \mathrm{C} 3 \\
\text { Skin necrosis after surgery } \\
\text { DM type II } \\
\end{array}$ & $\mathrm{f}$ & 65 & $48 \mathrm{hrs}$ & None & 83 \\
\hline 10. & $\begin{array}{c}\text { Oncological total knee } \\
\text { arthroplasty, skin necrosis after } \\
\text { surgery }\end{array}$ & $\mathrm{f}$ & 74 & 1 week & None & 70 \\
\hline
\end{tabular}

Note: AO - Association of Osteosynthesis, classification of fractures

G-A - the degree of tissue damage according to Gustilo-Anderson

$\mathrm{DM}$ - diabetes mellitus

ing. Elevation of MGF was carried out according to the described methods. The patient was in the supine position with the leg bent at the knee joint with slight external rotation. Direct access along the medial edge of the m. gastrocnemius from the popliteal fossa to the Achilles tendon was: $2-3 \mathrm{~cm}$ posteriorly to the posterior edge of the tibia if the muscle will move directly into the defect; $6-7 \mathrm{~cm}$ posteriorly to the posterior edge of the tibia if the muscle was planned to be carried out in the subcutaneous tunnel. After skin incision, $v$. saphena magna was isolated and taken on a holder. The fascia of $m$. gastrocnemius and $m$. soleus was cutted and muscles were divided in such a way that the tendon of $m$. plantaris passed together with m.soleus. On the ventral surface, an interval was found between the medial and lateral heads of $m$. gastrocnemius; $n$. cutaneus surae medialis and $v$. saphena parva, which are located lateral to the midline at the level of the muscle-tendon junction, were identified between them. The medial head was cut from the Achilles tendon so that the distal end of the flap contained approximately $1 \mathrm{~cm}$ of tendon tissue. The tendon cuff was sutured and the medial head was cut off from the lateral one, $n$. cutaneus surae medialis and $v$. saphena parva departed together with the lateral head. The flap preparation was continued up to the popliteal fossa, where the neurovascular pedicle of the medial head was identified (a. surae medialis, $v v$. comitantes, $n$. motoricus). In most cases, there was no need to isolate the neuro-vascular pedicle to increase the mobility of the flap (Fig. 1).

The flap lifting was completed; the flap was moved into the defect directly or in the tunnel under the skin bridge. Excessive tension, bending, and twisting of the flap were strictly avoided. To place the distal end of the flap, the corresponding edge of the recipient wound was mobilized, and the tendon part of the flap was sewn into this "pocket"; the ends of the thread were brought out onto the skin. The flap was placed in the recipient site in such a way that the edges of the skin covered it by $0.5-1 \mathrm{~cm}$ from all sides. Drainages were installed: one in the donor site, the second under the flap. All skin wounds were sutured. The flap was rather tightly sewn over the epimysium to the edges of the skin wound. The covering of the muscle was performed with split-thickness or whole-layer skin flap immediately or a few days after the surgery. 


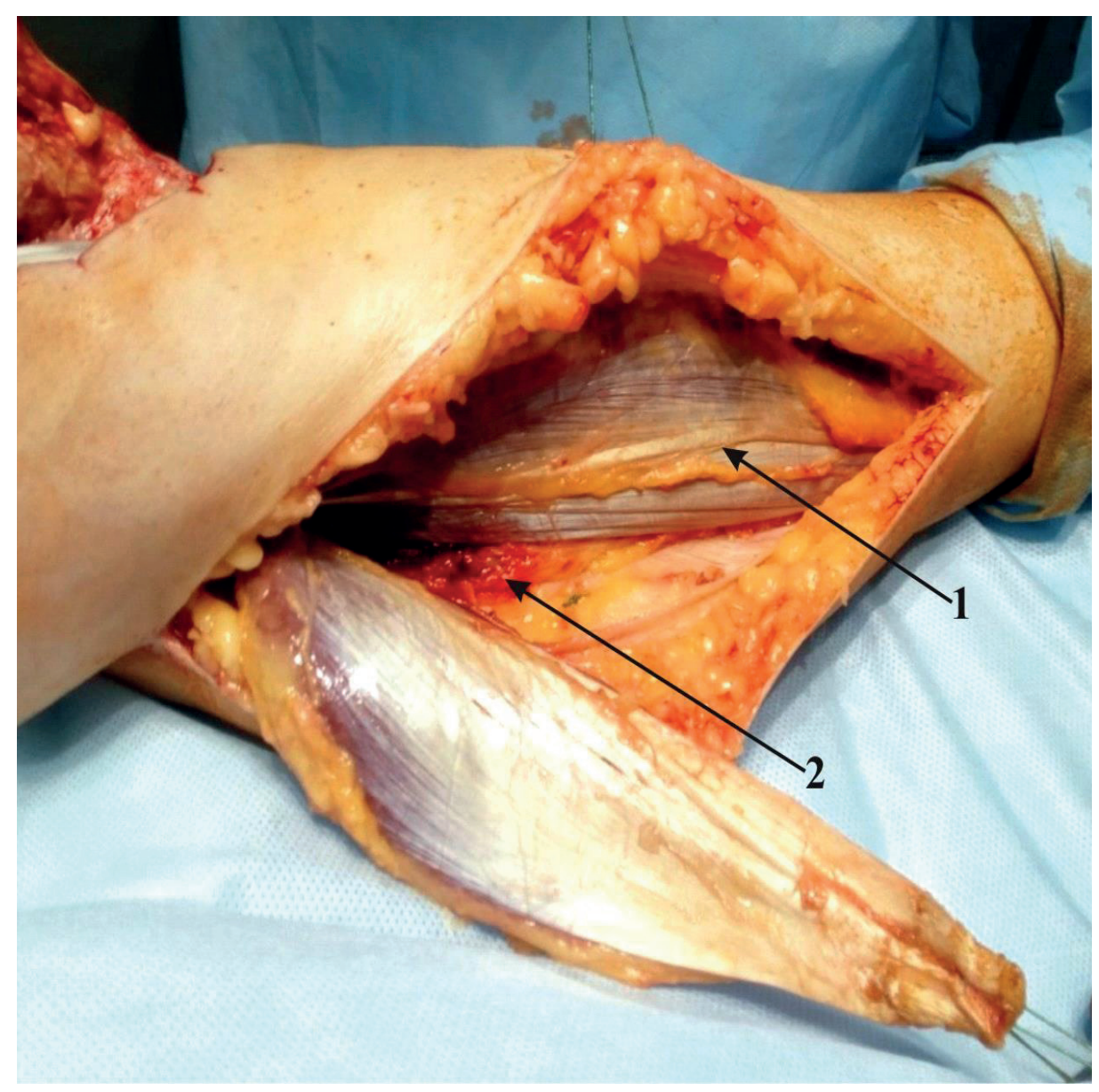

Fig. 1. The view of donor wound after the MGF elevation completed: $1-m$. plantaris Tendon; $2-n$. surae medialis, $v$. saphena parva

Fractures were stabilized with external fixators; in cases where preventive external fixation had already been performed, the external fixator was reassembled to free the knee joint. After healing of postoperative wounds (on average, 3-4 weeks after autodermoplasty), internal osteosynthesis and bone grafting were performed.

The results of treatment were assessed in terms of 9 months -10 years using the Lysholm scale.

\section{Results}

The course of the postoperative period in all cases was uncomplicated. Autodermoplasty during MGF transposition was performed in two cases, and a few days after the surgery in others. In cases of combat trauma, the MGF transposition was combined with the external fixator reassembly to free the knee joint. Conversion of osteosynthesis was carried out 1 month later by locking plate and substitution of the tibia defect by allogenic bone.

In cases when osteosynthesis was complicated by skin necrosis in the postoperative period, the knee joint was immobilized with an orthosis for two weeks after the MGF transposition.
The outcomes of treatment were assessed within 9 months - 10 years; full weight-bearing function of the lower limb was restored in all cases (Fig. 2). Knee function according to the Lysholm scale ranged from 70 to 100 points (mean $88.2 \pm 3.3$ points).

\section{Discussion}

Island MGF is one of the most used flaps in severe trauma of the upper third of the lower leg and complications after reconstructive surgery around the knee, i.g. total knee arthroplasty. Stable vascular anatomy, simple surgical technique, and the ability to close a section of the knee joint and the proximal third of the lower leg make MGF indispensable for open injuries of this area and skin complications of traumatic and another genesis.

M. gastrocnemius has a unique vascular anatomy: each of its heads has its own neurovascular pedicle about $5 \mathrm{~cm}$ long. Both pedicles starting slightly proximal to the knee joint [1]. The most commonly used is medial head of $\mathrm{m}$. gastrocnemius, which in adults has the following dimensions: $15-20 \mathrm{~cm}$ length and about $8 \mathrm{~cm}$ width [1]. 
Skin and soft tissues defects along the anterior surface of the knee joint and the proximal part of the leg resulting from trauma and other situations, require early closure due to the risk of osteomyelitis, loss of function of the knee joint and even amputation [6]. In particular, with open fractures of the proximal tibia, the infection of the surgical site can reach 45\% [7]. According to a meta-analysis of Henkelmann R. et al. [6], in 55.8\% of cases, after open fractures of the proximal tibia, various complications occur, of which the most important are non-union and pseudarthrosis (15.3\%), stiffness and ankylosis of the knee joint (18.7\%), and limb amputation (5.4\%).
A combat injury of the lower limb, especially mine-blast injury with smaller devices, is probably the most difficult problem for achieving acceptable anatomical and functional treatment results. One of the important points is the adequate debridement of devitalized tissues, which almost always causes a tissue defect of the lower leg [8].

Early and reliable closure of a soft tissue defect in some cases allows preserving a functioning limb [3]. Among our observations, there were 3 such cases; the use of MGF made it possible to carry out adequate control of infection in the early stages of treatment, which enabled further orthopedic reconstruction (Fig. 2).
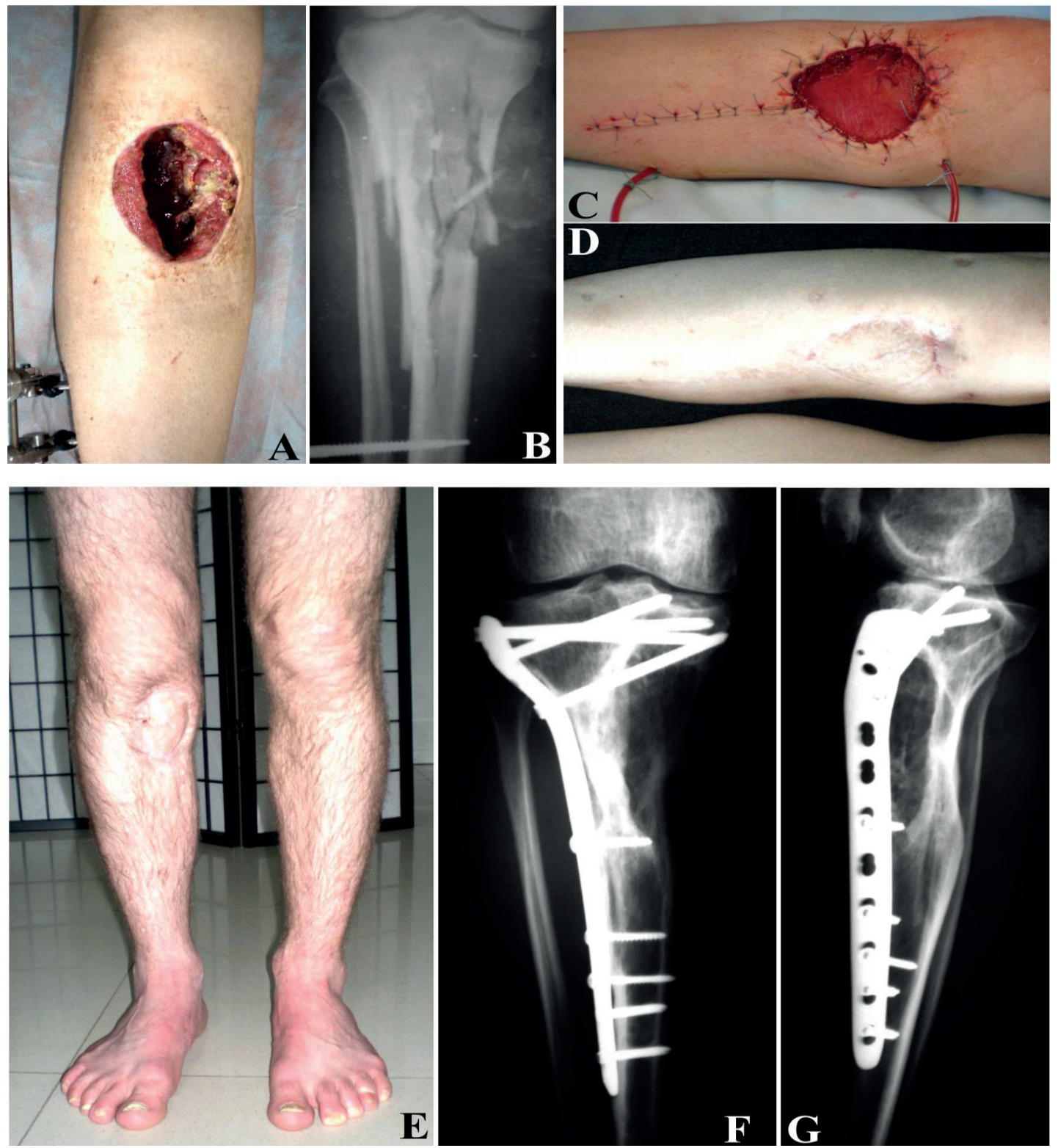

Fig. 2. Gunshot wound to the right lower leg (2015). Specialized assistance - surgical debridment and external fixation of the thigh-lower leg. After 2 weeks, necrectomy and replacement of the tissue defect with the MGF; autodermoplasty after 5 days. After 1 month, metal osteosynthesis with a locking compression plate and substitution of the tibia defect by allogenic bone graft. A and B - view of the wound and X-ray of the lower leg 2 weeks after the injury; C - after MGF transposition; D - a month after autodermoplasty; E, F, G - view of both lower limbs and X-rays of the right lower leg 1 year after osteosynthesis and bone grafting 
Fractures with traumatized but visually intact skin are especially difficult for treatment. Under such conditions, after osteosynthesis, necrosis of skin flaps can occur with exposure of bone and fixators. Recommendations for such cases in the modern literature include: necrectomy, vacuum assisted closure (VAC), and MGF transposition [9]. Among our observations, there were 4 similar cases. We applied one-step closure of the defect after necrectomy and got healing without complications.

Tetreault M.W. et al. [4] believe that the use of MGF is the best solution for infection after total knee arthroplasty due to skin necrosis, both to preserve the existing implant and in a two-stage procedure using a spacer. Their publication highlights the largest case series (31 patients) in the English-language literature. Among our observations, there was one similar case in a 74-yearold patient after oncological endoprosthesis.

\section{Conclusion}

MGF transposition for replacing tissue defects in the anterior surface of the lower leg and knee joint is an effective technique in orthopedic and traumatological practice, which allows solving the problem of infectious complications and preserving the musculoskeletal function of the lower limb. Stable vascular anatomy, simple surgical technique, and sufficient predictability of treatment results allow recommending this technique for wider application.

Conflict of interest. The authors declare no conflict of interest. This publication has not been, is not and will not be the subject of commercial interest in any form.

\section{References}

1. Mathes SJ, Nahai F. Classification of the vascular anatomy of muscles: experimental and clinical correlation. Plast Reconstr Surg. 1981; 67(2):177-87. PMID: 7465666.

2. D'Avila F, Franco D, D'avila B, Arnaut M, Jr. Use of local muscle flaps to cover leg bone exposures. Rev Col Bras Cir. 2014; 41(6):434-9. DOI: 10.1590/0100-69912014006009.

3. Ebrahimi A, Nejadsarvari N, Ebrahimi A, Rasouli HR. Early reconstructions of complex lower extremity battlefield soft tissue wounds. World J Plast Surg. 2017; 6(3):332-42. PMID: 29218283.

4. Tetreault MW, Della Valle CJ, Hellman MD, Wysocki RW. Medial gastrocnemius flap in the course of treatment for an infection at the site of a total knee arthroplasty. JBJS Essent Surg Tech. 2017;7(2):e14(1-13).

5. Veber M, Vaz G, Braye F, Carret JP, Saint-Syr M, Rohrich PJ, Mojallal A. Anatomical study of the medial gastrocnemius muscle flap: a quantitative assessment of the arc of rotation. Plast Rec Surg. 2011; 128(1):181-7. DOI: 10.1097/ PRS.0b013e318217423f.

6. Henkelmann R, Frosch KH, Glaab R, Lill H, Schoepp C, Seybold $\mathrm{D}$ et al. Infection following fractures of the proximal tibia - a systematic review of incidence and outcome BMC Musculoskelet Disord. 2017;18(1):481. DOI: 10.1186/s12891-017-1847-z.

7. Choo KJ, Morshed S. Postoperative complications after repair of tibial plateau fractures. J Knee Surg. 2014; 27(1):11-19. DOI: $10.1055 / \mathrm{s}-0033-1363517$.

8. Doucet JJ, Galarneau MR, Potenza BM, Bansal V, Lee JG, Schwartz AK et al. Combat versus civilian open tibia fractures: the effect of blast mechanism on limb salvage. J Trauma 2011; 70:1241-7. DOI: 10.1097/TA.0b013e3182095b52.

9. Cui H, Xiao H, He K, Peng Y, Bian Z, Wang H. V-Y advancement of medial gastrocnemius muscle flap for repairing soft tissue defects in middle and lower segments of anterior tibia. Zhongguo Xiu Fu Chong Jian Wai Ke Za Zhi. 2016; 30(9):11226. DOI: $10.7507 / 1002-1892.20160228$.

\section{Медіальний литковий клапоть для закриття дефектів тканин у ділянці колінного суглоба}

Лябах А.П., Лазаренко Г.М., Кулева О.В. ДУ "Інститут травматологї та ортопедії НАМН України", м. Київ

Резюме. Дефекти тканин передньої поверхні гомілки та колінного суглоба є серйозною проблемою при лікуванні пацієнтів з ортопедо-травматологічною патологією. мета. Аналіз результатів застосування медіального литкового клаптя (МЛК) у ортопедо-травматологічних пацієнтів, висвітлення особливостей хірургічної техніки. Матеріали і методи. 8 пачієнтів (10 випадків), яким була проведена транспозиція МЛК. Вік пащієнтів становив у середньому 40,5 55,7 року (19-74 років), чоловіків було 6, жінок - 2. Структура випадків: відкриті переломи 2 пацієнти, бойова травма - 2 пащієнти (3 випадки), некроз шкіри після остеосинтезу - 3 пацієнти (4 випадки), некроз шкіри після ендопротезування - 1 пацієнт. Очінка результатів лікування була проведена в строки від 9 місаців до 10 років за шкалою Lysholm. Результати. Аутодермопластика під час транспозицї̈ МЛК виконана в 2 випадках, в інших - через кілька днів. У випадках відкритих переломів виконували остеосинтез або перемонтаж АЗФ, конверсію остеосинтезу здіиснювали через 1 місящь після аутодермопластики. У випадках некрозу шкіри після остеосинтезу та ендопротезування металоконструкиї в жодному випадку не ви- 
даляли. Функція колінного суглоба за шкалою Lysholm становила від 70 до 100 балів (у середнъому 88,2 3,3 бала). Висновки. Транспозщиія МЛК для замімення дефектів тканин передньої поверхні гомілки та колінного суглоба є ефективною методикою в ортопедо-травматологічній практищі, що дозволяє розв'язати проблему інфекційних ускладнень та зберегти опорно-кінематичну функцію нижньої кінцівки.

ключові слова: гомілка; медіальний литковий клапоть; відкритий перелол; дефект тканин.

\section{Медиальный икроножный лоскут для закрытия дефектов тканей в области коленного сустава}

Лябах А.П., Лазаренко Г.Н., Кулева А.В.

ГУ "Институт травматологии и ортопедии НАМН Украины", г. Киев

Резюме. Дефекты тканей передней поверхности голени и коленного сустава являются серьезной проблемой в лечении пачиентов с ортопедо-травматологической патологией. Цель. Анализ результатов использования медиального икроножного лоскута (МИЛ) у ортопедо-травматологических пациентов, освещение особенностей хирургической техники. Материалы и методы. 8 пащиентов (10 случаев), которым была проведена транспозищия МИЛ. Возраст пащиентов составил в среднем 40,5士5,7 года (19-74), мужчин было 6, женщин - 2. Структура случаев: открытые переломы - 2 пащиента, боевая травма - 2 пащиента (3 случая), некроз кожи после остеосинтеза - 3 пащиента (4 случая), некроз кожи после эндопротезирования - 1 пациент. Оченка результатов лечения была проведена в сроки от 9 месяцев до 10 лет по шкале Lysholm. Результаты. Аутодермопластика во время транспозищи МИЛ выполнена в 2 случаях, в остальных - через несколько дней. В случаях открытых переломов проводили остеосинтез или перемонтаж АЗФ, конверсию остеосинтеза проводили через 1 месяи после аутодермопластики. В случаях некроза кожи после остеосинтеза и эндопротезирования металлоконструкиии ни в одном случае не удаляли. Функиия коленного сустава по шкале Lysholm cocma-

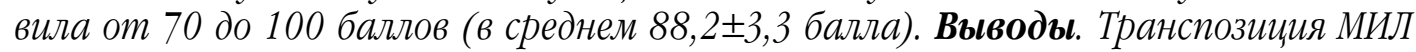
для замещения дефектов тканей передней поверхности голени и коленного сустава является эффективной методикой в ортопедо-травматологической практике, которая позволяет решить проблему инфекиионных осложнений и сохранить опорно-кинематическую функиию нижней конечности.

Ключевые слова: голень; медиальный икроножный лоскут; открытый перелом; дефект тканей.

\section{Відомості про авторів:}

Лябах Андрій Петрович - доктор медичних наук, професор, завідувач відділу патологї стопи та складного протезування ду "Інститут травматології та ортопедї НАМН Украӥни", вул. Бульварно-Кудрявська, 27, Київ, 01601, украӥна. ORCID: 0000-0001-5734-2392.

Лазаренко Галина Миколаӥвна - кандидат медичних наук, співробітник відділу патології стопи та складного протезування ду "Інститут травматологї та ортопедї НАМН України", вул. Бульварно-Кудрявська, 27, Київ, 01601, Україна.

Кулева Олександр Валерійович - кандидат медччних наук, співробітник ду "Інститут травматології та ортопедї НАМН України", вул. Бульварно-Кудрявсъка, 27, Київ, 01601, україна.

\section{Information about the authors:}

Liabakh Andrii Petrovych - D.Med.Sc., professor, head of the Department of Foot Pathology and Complex Prosthetics, SI "Institute of Traumatology and Orthopedics of NAMS of Ukraine", 27 Bulvarno-Kudriavska St., Kyiv, 01601, Ukraine. ORCID: 0000-0001-5734-2392. 
Lazarenko Halyna Mykolaivna - Ph.D. in Medicine, the Department of Foot Pathology and Complex Prosthetics, SI "Institute of Traumatology and Orthopedics of NAMS of Ukraine", 27 Bulvarno-Kudriavska St., Kyiv, 01601, Ukraine.

Kulieva Oleksandr Valeriiovych - Ph.D. in Medicine, Department of Foot Pathology and Complex Prosthesis, SI "Institute of Traumatology and Orthopedics of NAMS of Ukraine", 27 Bulvarno-Kudriavska St., Kyiv, 01601, Ukraine.

\section{Сведения об авторах:}

Лябах Андрей Петрович - доктор медиинских наук, профессор, заведующий отделом патологии стопы и сложного протезирования Гу "Институт травматологии и ортопедии НАМН Украины", ул. Бульварно-Кудрявскал, 27, Киев, 01601, Украина. ORCID: 0000-0001-5734-2392.

ЛазаренкоГалинаниколаевна-кандидатмедииинскихнаук, сотрудникотдела патологии стопы и сложного протезирования Гу "Институт травматологии и ортопедии НАМН Украины", ул. Бульварно-Кудрявская, 27, Киев, 01601, Украина.

КулеваАлександр Валериевич - кандидатмедицинскихнаук, сотрудникотдела патологии стопы и сложного протезирования ГУ "Институт травматологии и ортопедии НАМН Украины”, ул. Бульварно-Кудрявская, 27, Киев, 01601, Украина.

Для листування: Лябах Андрій Петрович, завідувач відділу патології стопи та складного протезування ДУ "Інститут травматології та ортопедії НАМН України", вул. Бульварно-Кудрявська, 27, Київ, 01601, Україна. Тел. +38(097)901-03-64. E-mail: anliabakh@gmail.com.

For correspondence: Liabakh Andrii Petrovych, head of the Department of Foot Pathology and Complex Prosthetics, SI "Institute of Traumatology and Orthopedics of NAMS of Ukraine”, 27 Bulvarno-Kudriavska St., Kyiv, 01601, Ukraine. Tel. +38(097)901-0364. E-mail: anliabakh@gmail.com

Для корреспонденции: Лябах Андрей Петрович, заведующий отделом патологии стопы и сложного протезирования Гу "Институт травматологии и ортопедии НАМН Украины”, ул. Бульварно-Кудрявская, 27, Киев, 01601, Украина. Тел. +38(097)90103-64. E-mail: anliabakh@gmail.com. 